\title{
Metode REBA Untuk Pencegahan Musculoskeletal Disorder Tenaga Kerja
}

\author{
Dian Palupi Restuputri, M. Lukman, Wibisono \\ Teknik Industri, Teknik, Universitas Muhammadiyah Malang \\ Jl. Raya Tlogomas 246 Malang 65144 Jawa Timur, Telp. (0341) 464318/Fax (0341) 460782 \\ *Surel: restuputri@yahoo.com
}

\begin{abstract}
$C V$. Wijaya Kusuma is a company producing sanitair. The production process is done manually. Workers work with work postures bent and squatting. Posture work bent and squat reduces the comfort. Posture work bend and squat and potential risks of musculoskeletal disorder. REBA method is suitable to solve the problem. REBA is a method used in job posture analysis. REBA method used to quickly assess the posture of the neck, back, arms, wrists, and feet of a worker. The initial stage of the research is to divide the Nordic Body Map (NBM) questionnaire. NBM aims to know complaints of body parts before and after work. The purpose study is to determine the cause of complaints of musculoskeletal disorders (MSDs) labor. This study provides a solution to the problem of labor MSDs complaints. The results show 6 work postures with "moderate" risk levels, 4 high-risk "work postures". All work postures in the sanitair production process require corrective action posture.
\end{abstract}

Keywords: Ergonomic, Musculoskeletal Disorder, Nordic Body Map, REBA

\begin{abstract}
Abstrak
CV. Wijaya Kusuma adalah perusahaan yang memproduksi sanitair. Proses produksi dilakukan secara manual. Tenaga kerja bekerja dengan postur kerja membungkuk dan jongkok. Postur kerja membungkuk dan jongkok mengurangi kenyamanan tenaga kerja. Postur kerja membungkuk dan jongkok kurang ergonomis dan berpotensi menimbulkan risiko musculoskeletal disorder. Metode REBA cocok untuk memecahkan masalah tersebut. REBA adalah merupakan metode yang digunakan dalam analisa postur kerja. Metode REBA digunakan secara cepat untuk menilai postur leher, punggung, lengan, pergelangan tangan, dan kaki seorang pekerja. Tahapan awal penelitian adalah melakukan pembagian kuesioner Nordic Body Map (NBM). NBM bertujuan mengetahui keluhan bagian tubuh sebelum dan sesudah bekerja. Tujuan penelitian ini adalah mengetahui penyebab terjadinya keluhan musculoskeletal disorders (MSDs) tenaga kerja. Penelitian ini memberikan solusi permasalahan keluhan MSDs tenaga kerja. Hasil penelitian menunjukkan 6 postur kerja dengan level risiko "sedang", 4 postur kerja dengan resiko "tinggi". Seluruh postur kerja di proses produksi sanitair memerlukan tindakan perbaikan postur kerja.
\end{abstract}

Kata kunci: Ergonomi, Gangguan Musculoskeletal, Nordic Body Map, REBA

\section{Pendahuluan}

Ergonomi berkenaan pula dengan optimasi, efisiensi, kesehatan, keselamatan dan kenyamanan manusia di tempat kerja, dirumah, dan di tempat rekreasi. Didalam ergonomi dibutuhkan studi tentang sistem di mana manusia, fasilitas kerja dan lingkungannya saling berinteraksi dengan tujuan utama yaitu menyesuaikan suasana kerja dengan manusianya [1]. Keluhan musculoskeletal adalah keluhan pada bagianbagian otot skeletal yang dirasakan oleh seseorang mulai dari keluhan sangat ringan sampai sangat sakit. Apabila otot menerima beban statis secara berulang dan dalam waktu yang lama, akan dapat menyebabkan keluhan berupa kerusakan pada sendi, 
ligamen dan tendon. Keluhan hingga kerusakan inilah yang biasanya diistilahkan dengan keluhan musculoskeletal disorders (MSDs) atau cedera pada sistem musculoskeletal [2].

CV. Wijaya Kusuma merupakan perusahaan pembuat sanitair, pot, air mancur, dan gipsum. Di perusahaan, para tenaga kerjanya masih menggunakan cara yang tradisional tanpa membutuhkan mesin automatis atau semi automatis. Tenaga kerja di departemen produksi dinilai bekerja kurang ergonomis. Posisi kerja para tenaga kerja saat mengambil bahan baku dan mengaduk bahan baku dengan posisi membungkuk. Sedangkan pada proses pembentukan sanitair, tenaga kerja bekerja dengan jongkok tanpa menggunakan kursi dan meja. Posisi kerja tersebut mengurangi kenyamanan tenaga kerja dan berpotensi menimbulkan penyakit akibat kerja dikarenakan proses produksi tersebut dilakukan dengan jangka waktu yang lama sekitar 7-8 jam [3]. Hasil wawancara awal kepada para tenaga kerja diketahui terdapat keluhan sakit punggung saat bekerja. Oleh karena itu, diperlukan suatu metode analisis postur kerja guna mengurangi gangguan musculoskeletal yang sering dialami oleh para karyawan.

Metode REBA (Rapid Entire Body Assessment) digunakan untuk menganalisis postur tubuh para tenaga kerja di CV. Wijaya Kusuma saat produksi. Higgnet and Mcatamney [4] mengemukakan metode REBA secara cepat dapat menilai resiko tubuh bagian tubuh atas. Metode REBA relatif mudah digunakan karena untuk mengetahui nilai suatu postur tubuh tidak diperlukan besar sudut yang spesifik, hanya berupa range sudut [3]. Diharapkan dengan mengaplikasikan metode REBA di CV. Wijaya Kusuma dapat mengurangi keluhan - keluhan sakit punggung yang dialami oleh para tenaga kerja produksi dan tidak mengurangi performa kerja serta mengganggu pekerjaan.

\section{Metode Penelitian}

Tahapan pertama adalah mengidentifikasi keluhan berdasarkan Nordic Body Map (NBM). Nordic Body Map merupakan kuesioner berupa peta tubuh yang berisikan data bagian tubuh yang dikeluhkan oleh para pekerja. Kuesioner Nordic Body Map adalah kuesioner yang paling sering digunakan untuk mengetahui ketidaknyamanan pada para pekerja, dan kuesioner ini paling sering digunakan karena sudah terstandaerisasi dan tersusun rapi [5]. Menurut Tarwaka and Sudiajeng [2], dengan melihat dan menganalisis peta tubuh (NBM) seperti pada Gambar 1 dapat diestimasi jenis dan tingkat keluhan otot skeletal yang dirasakan pekerja. NBM sangat sederhana namun kurang teliti dikarenakan mengandung subjektivitas tinggi. Untuk mengurangi subjektivitas lakukan pengisian kuesioner sebelum dan sesudah melakukan aktivitas kerja (pre and post test).

Tahapan selanjutnya adalah mengukur risiko dengan metode REBA. Metode REBA digunakan secara cepat untuk menilai postur leher, punggung, lengan, pergelangan tangan, dan kaki seorang pekerja. Langkah-langkah penentuan skor REBA adalah pertama menghitung skor pada tabel A yang terdiri dari leher (neck), batang tubuh (trunk), dan kaki (legs). Langkah kedua menghitung tabel B yang terdiri dari lengan atas (upper arm), lengan bawah (lower arm), dan pergelangan tangan (wrist). Setelah didapatkan skor akhir tabel A dan B maka dimasukkan ke dalam tabel C yang kemudian menentukan kategori tindakannya. 13 langkah penentuan skor REBA dapat dilihat pada Gambar 2. 


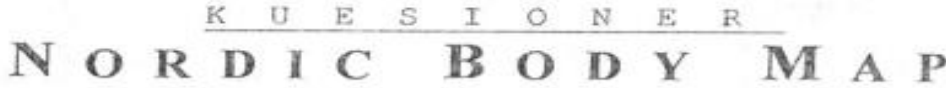

Pekerja No:

\begin{tabular}{|c|c|c|c|c|c|}
\hline \multirow{2}{*}{ No } & \multirow{2}{*}{ Keluhan } & \multicolumn{2}{|c|}{$\begin{array}{c}\text { Sebelum } \\
\text { Kerja }\end{array}$} & \multicolumn{2}{|c|}{$\begin{array}{l}\text { Sesudah } \\
\text { Kerja }\end{array}$} \\
\hline & & $\mathbf{Y a}$ & rdk & Ya & Tdk \\
\hline 0 & Sakit pada leher bagian atas & & & & \\
\hline 1 & Sakit pada leher bagian bawah & & & & \\
\hline 2 & Sakit pada bahu kiri & & & & \\
\hline 3 & Sakit pada bahu kanan & & & & \\
\hline 4 & Sakit pada lengan atas bagian kiri & & & & \\
\hline 5 & Sakit pada bagian punggung & & & & \\
\hline 6 & Sakit pada lengan atas bagian kanan & & & & \\
\hline 7 & Sakit pada pinggang & & & & \\
\hline 8 & Sakit pada bokong & & & & \\
\hline 9 & Sakit pada pantat & & & & \\
\hline 10 & Sakit pada siku kiri & & & & \\
\hline 11 : & Sakit pada siku kanan & & & & \\
\hline 12 & Sakit pada lengan bawah bagian kiri & & & & \\
\hline $13:$ & Sakit pada lengan bawah bagian kanan & & & & \\
\hline 14 & Sakit pada pergelangan tangan kiri & & & & \\
\hline 15 & Sakit pada pergelangan tangan kanan & & & & - \\
\hline 16 & Sakit pada tangan bagian kiri & & & & \\
\hline 17 & Sakit pada tangan bagian kanđి & & & & \\
\hline 18 & Sakit pada paha kiri & & & & \\
\hline 19 & Sakit pada paha kanan & & & & \\
\hline 20 & Sakit pada lutut kiri & & & & \\
\hline $21:$ & Sakit pada lutut kanan & & & & \\
\hline $22:$ & Sakit pada betis kiri & & & & \\
\hline 23 & Sakit pada betis kanan & & & & \\
\hline 24 & Sakit pada pergelangan kaki kiri & & & & \\
\hline 25 & Sakit pada pergelangan kaki kanan & & & & \\
\hline 26 & Sakit pada kaki kiri & & & & \\
\hline 27 & Sakit pada kaki kanan & & & & \\
\hline
\end{tabular}

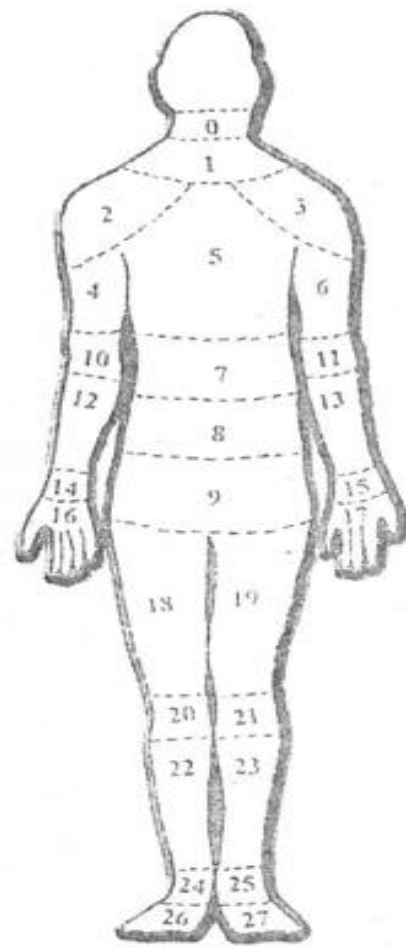

Gambar 1 Kuesioner NBM

\section{Hasil dan Pembahasan}

Pengumpulan data dilakukan dengan melakukan pengamatan pada para pekerja di ruang produksi CV. Wijaya Kusuma. Proses produksi pembuatan sanitair terdiri dari pengadukan bahan baku, melapisi cetakan dengan oli, proses pencetakan awal, pemberian rangka, proses pencetakan akhir, pelepasan cetakan, proses ukir hingga proses finishing. Gambar postur kerja yang diambil merupakan persentase keluhan terbesar dari seluruh gerakan yang dilakukan di setiap proses pengerjaan sanitair.

\subsection{Identifikasi MSDs menggunakan Nordic Body Map}

Tahapan pertama adalah mengidentifikasi keluhan berdasarkan $N B M$ pada para tenaga kerja produksi wahana sanitair di CV. Wijaya Kusuma. Hasil kuesioner NBM tersebut di rekapitulasi berdasarkan hasil keluhan. Persentase keluhan sesudah bekerja menurut hasil pembagian kuesioner dapat dilihat pada Tabel 1. 


\section{ERGONCMICS REBA Employee Assessment Worksheet Task Name:}

A. Neck, Trunk and Leg Analysis Step 1: Locate Neck Position
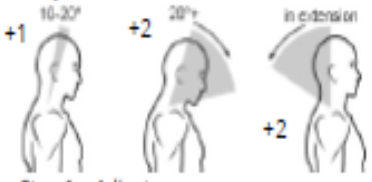

If neck is twisted.

If neck is side bending: +1

Step 2: Locate Trunk Position
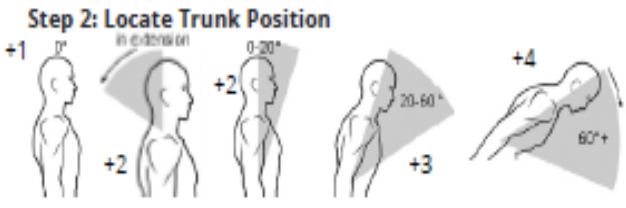

Step 2a: Adjust.

If trunk is twisted: +1

If trunk is side bending +1

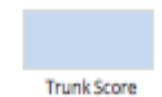

Step 3: Legs

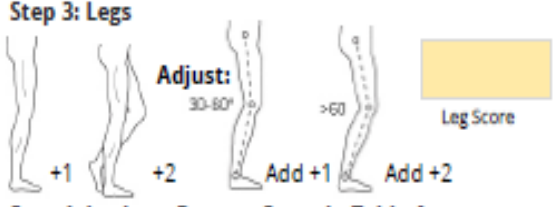

Step 4: Look-up Posture Score in Table A Using values from steps 1-3 above,

Locate score in Table A

Step 5: Add Force/Load Score

If load $<11 \mathrm{lbs},:+0$

If load 11 to $22 \mathrm{lbs}:$ : +1

If load $>22$ lbs.: +2

Adjust: If shock or rapid build up of force: add +1 force / Lasd Score

Step 6: Score A, Find Row in Table C

Add values from steps 4 \& 5 to obtain Score A.

Find Row in Table C.

Scoring

1 - Negligible Risk

2.3 - Low Risk. Change may be needed.

4.7 - Medium Risk. Further Investigate. Change Soon.

8-10 = High Risk. Investigate and Implement Change

$11+$ = Very High Risk. Implement Change
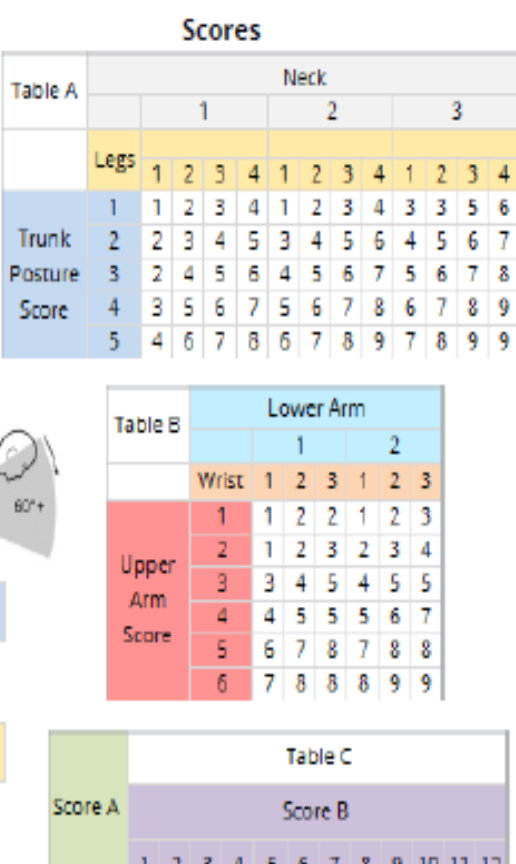

$\begin{array}{llllllllllll}1 & 2 & 3 & 4 & 5 & 6 & 7 & 8 & 9 & 10 & 11 & 12\end{array}$ \begin{tabular}{lllllllllllll}
1 & 1 & 1 & 1 & 2 & 3 & 3 & 4 & 5 & 6 & 7 & 7 & 7 \\
\hline
\end{tabular} \begin{tabular}{lllllllllllll|l|l|l}
2 & 1 & 2 & 2 & 3 & 4 & 4 & 5 & 6 & 6 & 7 & 7 & 8
\end{tabular} \begin{tabular}{llllll|l|l|l|l|l|l|l|l|}
3 & 2 & 3 & 3 & 3 & 4 & 5 & 6 & 7 & 7 & 8 & 8 & 8
\end{tabular} $\begin{array}{llllllllllllll}4 & 3 & 4 & 4 & 4 & 5 & 6 & 7 & 8 & 8 & 9 & 9 & 9\end{array}$ \begin{tabular}{llllllllll|l|l|l|l|}
5 & 4 & 4 & 4 & 5 & 6 & 7 & 8 & 8 & 9 & 9 & 9 & 9
\end{tabular} $\begin{array}{llllllllllllll}6 & 6 & 6 & 6 & 7 & 8 & 8 & 9 & 9 & 10 & 10 & 10 & 10\end{array}$ $\begin{array}{lllllllllllllll}7 & 7 & 7 & 7 & 8 & 9 & 9 & 9 & 10 & 10 & 11 & 11 & 11\end{array}$

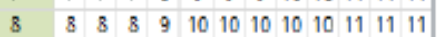
$\begin{array}{lllllllllllll}9 & 9 & 9 & 9 & 10 & 10 & 10 & 11 & 11 & 11 & 12 & 12 & 12\end{array}$ $\begin{array}{lllllllllllllll}10 & 10 & 10 & 10 & 11 & 11 & 11 & 11 & 12 & 12 & 12 & 12 & 12\end{array}$ \begin{tabular}{llllllllllllll|}
11 & 11 & 11 & 11 & 11 & 12 & 12 & 12 & 12 & 12 & 12 & 12 & 12 \\
\hline
\end{tabular} $\begin{array}{llllllllllllll}12 & 12 & 12 & 12 & 12 & 12 & 12 & 12 & 12 & 12 & 12 & 12 & 12\end{array}$

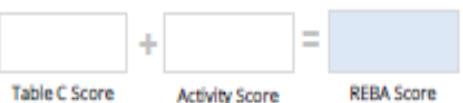

B. Arm and Wrist Analysis

Step 7: Locate Upper Arm Position:

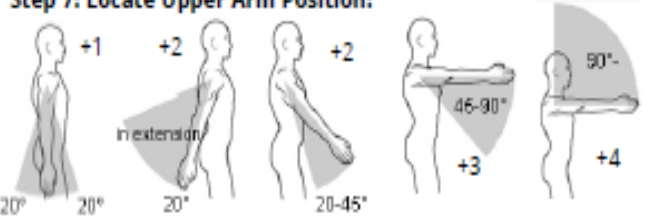

Step 7a: Adiust.

If shoulder is raised: +1

If upper arm is abducted: +1

If arm is supported or person is leaning:-1

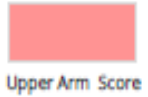

Steo 8: Locate Lower Arm Position:
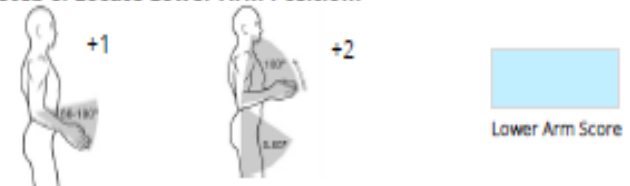

Steo 9: Locate Wrist Position:

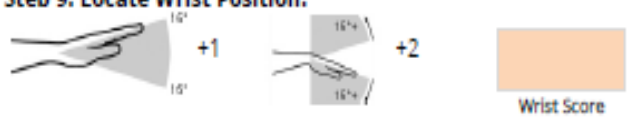

Step 9a: Adjust.

If wrist is bent from midline or twisted: Add +1

Step 10: Look-up Posture Score in Table B

Using values from steps 7.9 above, locate score in Tabie B

Step 11: Add Coupling Score

Well fitting Handle and mid rang power grip, good: to

Acceptable but not ideal hand hold or coupling

acceptable with another body part, fair: +1

Hand hold not acceptable but possible, poor: +2

No handles, awkward, unsafe with any body part,

Unacceptable: 43

Step 12: Score B, Find Column in Table C

Add values from steps 10 \&:11 to obtain

Score B. Find column in Table C and match with

Score A in row from step 6 to obtain Table C Score.

Step 13: Activity Score

+11 or more body parts are held for longer than 1 minute (static)

+1 Repeated small range actions (more than $4 x$ per minute)

+1 Action causes rapid large range changes in postures or unstable base

Gambar 2 Lembar Kerja Penilaian Metode REBA

Berdasarkan Tabel 1, persentase kuesioner NBM yang dikumpulkan dari seluruh tenaga kerja terdapat 12 bagian tubuh yang dikeluhkan mengalami sakit pada bagian tubuh tersebut. Keluhan yang paling banyak dirasakan oleh para tenaga kerja produksi sesudah bekerja adalah :

Keluhan sebanyak 3 orang tenaga kerja produksi dengan persentase $75 \%$ dirasakan pada bagian tubuh :

1. Sakit kaku pada bagian leher atas

2. Sakit di bahu kanan

3. Sakit lengan atas kanan

4. Sakit lengan bawah kiri

5. Sakit pada pergelangan tangan kanan

6. Sakit pada paha kiri

7. Sakit pada paha kanan

8. Sakit pada betis kiri 
Keluhan sebanyak 4 orang tenaga kerja produksi dengan persentase $100 \%$ dirasakan pada bagian tubuh :

1. Sakit di punggung

2. Sakit pada pinggang

3. Sakit lengan bawah kanan

4. Sakit pada betis kanan

Tabel 1 Persentase keluhan sesudah bekerja menurut hasil pembagian kuesioner Nordic Body Map

\begin{tabular}{|c|c|c|c|c|c|}
\hline \multirow{3}{*}{ No. } & \multirow{3}{*}{ Jenis Keluhan } & \multicolumn{4}{|c|}{ Tingkat Keluhan Sesudah Berkerja } \\
\hline & & \multicolumn{2}{|c|}{ Tidak Sakit } & \multicolumn{2}{|c|}{ Sakit } \\
\hline & & Jumlah & $\%$ & Jumlah & $\%$ \\
\hline 0. & Sakit kaku pada bagian leher atas & 1 & 25 & 3 & 75 \\
\hline 1. & Sakit kaku pada bagian leher bawah & 2 & 50 & 2 & 50 \\
\hline 2. & Sakit di bahu kiri & 3 & 75 & 1 & 25 \\
\hline 3. & Sakit di bahu kanan & 1 & 25 & 3 & 75 \\
\hline 4. & Sakit lengan atas kiri & 3 & 75 & 1 & 25 \\
\hline 5. & Sakit di punggung & 0 & 0 & 4 & 100 \\
\hline 6. & Sakit lengan atas kanan & 1 & 25 & 3 & 75 \\
\hline 7. & Sakit pada pinggang & 0 & 0 & 4 & 100 \\
\hline 8. & Sakit pada bokong & 2 & 50 & 2 & 50 \\
\hline 9. & Sakit pada pantat & 3 & 75 & 1 & 25 \\
\hline 10. & Sakit pada siku kiri & 4 & 100 & 0 & 0 \\
\hline 11. & Sakit pada siku kanan & 4 & 100 & 0 & 0 \\
\hline 12. & Sakit lengan bawah kiri & 1 & 25 & 3 & 75 \\
\hline 13. & Sakit lengan bawah kanan & 0 & 0 & 4 & 100 \\
\hline 14. & Sakit pada pergelangan tangan kiri & 3 & 75 & 1 & 25 \\
\hline 15. & Sakit pada pergelangan tangan kanan & 1 & 25 & 3 & 75 \\
\hline 16. & Sakit pada tangan kiri & 4 & 100 & 0 & 0 \\
\hline 17. & Sakit pada tangan kanan & 4 & 100 & 0 & 0 \\
\hline 18. & Sakit pada paha kiri & 1 & 25 & 3 & 75 \\
\hline 19. & Sakit pada paha kanan & 1 & 25 & 3 & 75 \\
\hline 20. & Sakit pada lutut kiri & 3 & 75 & 1 & 25 \\
\hline 21. & Sakit pada lutut kanan & 4 & 100 & 0 & 0 \\
\hline 22. & Sakit pada betis kiri & 1 & 25 & 3 & 75 \\
\hline 23. & Sakit pada betis kanan & 0 & 0 & 4 & 100 \\
\hline 24. & Sakit pada pergelangan kaki kiri & 2 & 50 & 2 & 50 \\
\hline 25. & Sakit pada pergelangan kaki kanan & 2 & 50 & 2 & 50 \\
\hline 26. & Sakit pada kaki kiri & 3 & 75 & 1 & 25 \\
\hline 27. & Sakit pada kaki kanan & 3 & 75 & 1 & 25 \\
\hline
\end{tabular}

\subsection{Identifikasi MSDs dengan menggunakan REBA}

Gambar 3 menunjukkan postur kerja tenaga kerja sedang mengaduk bahan baku. Perekaman postur kerja tenaga kerja produksi sanitair menggunakan gambar aktivitas. Aktivitas tersebut kemudian diolah dengan menggunakan metode REBA. 


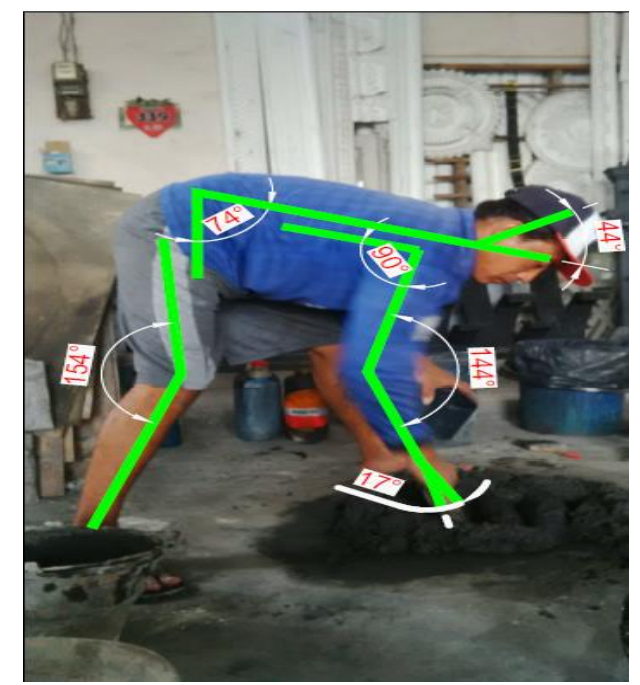

Gambar 3 Postur kerja tenaga kerja sedang mengaduk bahan baku

Seorang pekerja memiliki sikap kerja seperti Gambar 3. Scoring postur tubuh proses pengadukan bahandapat dilihat pada Tabel 2 .

Tabel 2 Scoring postur tubuh proses pengadukan bahan

\begin{tabular}{lclc}
\hline \multicolumn{1}{c}{ Postur Tubuh } & Skor & \multicolumn{1}{c}{ Keterangan } & Skor Akhir \\
\hline $\begin{array}{l}\text { Leher (neck) } \\
\begin{array}{l}\text { Batang tubuh } \\
\text { trunk) }\end{array}\end{array}$ & 2 & $\begin{array}{l}44^{0} \text { ke depan } \\
74^{0} \text { ke depan }\end{array}$ & 4 \\
Kaki (legs) & 2 & $\begin{array}{l}\text { Kaki tidak seimbang, }+2 \\
\text { karena kaki membentuk } \\
\text { sudut } 154^{0}\end{array}$ & 4 \\
\hline
\end{tabular}

Tabel 3 Skor tabel A proses pengadukan bahan baku

\begin{tabular}{|c|c|c|c|c|c|c|c|c|c|c|c|c|c|}
\hline \multirow{3}{*}{ Table A } & \multicolumn{13}{|c|}{ Neck } \\
\hline & & \multicolumn{4}{|c|}{1} & \multicolumn{4}{|c|}{2} & \multicolumn{4}{|c|}{3} \\
\hline & Legs & 1 & 2 & 3 & 4 & 1 & 2 & 3 & (4) & 1 & 2 & 3 & 4 \\
\hline & 1 & 1 & 2 & 3 & 4 & 1 & 2 & 3 & 4 & 3 & 3 & 5 & 6 \\
\hline Trunk & 2 & 2 & 3 & 4 & 5 & 3 & 4 & 5 & 6 & 4 & 5 & 6 & 7 \\
\hline Posture & 3 & 2 & 4 & 5 & 6 & 4 & 5 & 6 & 7 & 5 & 6 & 7 & 8 \\
\hline \multirow[t]{2}{*}{ Score } & (4) & 3 & 5 & 6 & 7 & 5 & 6 & 7 & 8 & 6 & 7 & 8 & 9 \\
\hline & 5 & 4 & 6 & 7 & 8 & 6 & 7 & 8 & 9 & 7 & 8 & 9 & 9 \\
\hline
\end{tabular}

Sikap kerja tenaga kerja produksi pada aktivitas pencampuran semen-cat bubukair menunjukkan leher diberi skor 2 karena bergerak $44^{\circ}$ ke depan, batang tubuh diberi skor 4 karena tubuh $74^{\circ}$ ke depan, dan kaki diberi skor 2 karena posisi kaki tidak seimbang serta diberikan +2 dikarenakan kaki membentuk sudut $154^{\circ}$, sehingga skor akhir kaki adalah 4. Skor yang didapat dari hasil pengamatan postur leher, batang tubuh dan kaki saat bekerja skor tersebut dimasukkan ke dalam tabel A dan didapatkan skor 8 (Tabel 3). 
Tabel 4 Scoring postur tubuh proses pengadukan bahan

\begin{tabular}{lclc}
\hline \multicolumn{1}{c}{ Postur Tubuh } & Skor & Keterangan & $\begin{array}{c}\text { Skor } \\
\text { Akhir }\end{array}$ \\
\hline $\begin{array}{l}\text { Lengan atas (upper } \\
\text { arm) }\end{array}$ & 3 & $90^{0}$ ke depan & 3 \\
$\begin{array}{l}\text { Lengan bawah (lower } \\
\text { arm) }\end{array}$ & 2 & $144^{0}$ ke depan & 2 \\
$\begin{array}{l}\text { Pergelangan tangan } \\
\text { (wrist) }\end{array}$ & 2 & $\begin{array}{l}17^{0} \text { ke bawah, +1 karena } \\
\text { pergelangan berputar }\end{array}$ & 3 \\
\hline
\end{tabular}

Tabel 5 Skor tabel B proses pengadukan bahan baku

\begin{tabular}{|c|c|c|c|c|c|c|c|}
\hline \multirow{3}{*}{ Table B } & \multicolumn{7}{|c|}{ Lower Arm } \\
\hline & & & 1 & & & (2) & \\
\hline & Wrist & 1 & 2 & 3 & 1 & 2 & (3) \\
\hline \multirow{6}{*}{$\begin{array}{c}\text { Upper } \\
\text { Arm } \\
\text { Score }\end{array}$} & 1 & 1 & 2 & 2 & 1 & 2 & 3 \\
\hline & 2 & 1 & 2 & 3 & 2 & 3 & 4 \\
\hline & 3 & 3 & 4 & 5 & 4 & 5 & 5 \\
\hline & 4 & 4 & 5 & 5 & 5 & 6 & 7 \\
\hline & 5 & 6 & 7 & 8 & 7 & 8 & 8 \\
\hline & 6 & 7 & 8 & 8 & 8 & 9 & 9 \\
\hline
\end{tabular}

Pada Tabel 4 Sikap kerja dari tenaga kerja produksi proses mencampur semencat bubuk-air menunjukkan lengan atas diberi skor 3 karena bergerak $90^{\circ}$ ke arah depan, lengan bawah diberi skor 2 karena $144^{\circ}$ ke depan, pergelangan tangan diberi skor 2 karena $17^{\circ}$ ke arah bawah serta diberi tambahan skor +1 karena pergelangan tangan berputar sehingga skor akhir pergelangan tangan adalah 3 . Dengan skor yang didapat dari hasil mengamati postur lengan atas, lengan bawah dan pergelangan tangan saat bekerja skor tersebut dimasukkan ke dalam tabel B dan didapatkan skor 5 (Tabel 5) dan tidak ada penambahan skor pegangan, karena saat bekerja sudah memegang alat dengan pas.

Tabel 6 Skor tabel C proses pengadukan bahan baku

\begin{tabular}{|c|c|c|c|c|c|c|c|c|c|c|c|c|}
\hline \multirow{3}{*}{ 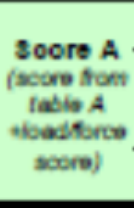 } & \multicolumn{12}{|c|}{ Table C } \\
\hline & \multicolumn{12}{|c|}{ Score B, (Aatib B valus tooupling score) } \\
\hline & 1 & 2 & 3 & 4 & (5) & 6 & 7 & 8 & 9 & 10 & 11 & 12 \\
\hline 1 & 1 & 1 & 1 & 2 & 3 & 3 & 4 & 5 & 6 & 7 & 7 & 7 \\
\hline 2 & 1 & 2 & 2 & 3 & 4 & 4 & 5 & 5 & 6 & 7 & 7 & B \\
\hline 3 & 2 & 3 & 3 & 3 & 4 & 5 & 6 & 7 & 7 & 8 & 8 & 8 \\
\hline 4 & 3 & 4 & 4 & 4 & 5 & 6 & 7 & 8 & 8 & 9 & 9 & 9 \\
\hline 5 & 4 & 4 & 4 & 5 & 6 & 7 & 8 & 8 & 9 & 9 & 9 & 9 \\
\hline 6 & 5 & 5 & 5 & 7 & 8 & 8 & 9 & 9 & 10 & 10 & 10 & 10 \\
\hline 7 & 7 & 7 & 7 & 8 & 9 & 9 & 9 & 10 & 10 & 11 & 11 & 11 \\
\hline 8 & 8 & 8 & 8 & 9 & 10 & 10 & 10 & 10 & 10 & 11 & 11 & 11 \\
\hline 9 & 9 & 9 & 9 & 10 & 10 & 10 & 11 & 11 & 11 & 12 & 12 & 12 \\
\hline 10 & 10 & 10 & 10 & 11 & 11 & 11 & 11 & 12 & 12 & 12 & 12 & 12 \\
\hline 11 & 11 & 11 & 11 & 11 & 12 & 12 & 12 & 12 & 12 & 12 & 12 & 12 \\
\hline 12 & 12 & 12 & 12 & 12 & 12 & 12 & 12 & 12 & 12 & 12 & 12 & 12 \\
\hline
\end{tabular}


Setelah memasukkan skor akhir tabel A \& B di tabel C maka di dapatkan skor 10 (Tabel 6) proses pengadukan semen-cat bubuk-air. Rekapitulasi scoring postur kerja proses produksi sanitair dapat dilihat pada Tabel 7 .

Tabel 7 Rekapitulasi scoring postur kerja proses produksi sanitair

\begin{tabular}{lccc}
\hline \multicolumn{1}{c}{ Postur Kerja } & $\begin{array}{c}\text { Skor } \\
\text { Tabel A }\end{array}$ & $\begin{array}{c}\text { Skor } \\
\text { Tabel B }\end{array}$ & $\begin{array}{c}\text { Skor } \\
\text { Tabel C }\end{array}$ \\
\hline Mencampur semen-cat bubuk-air & 8 & 5 & 10 \\
Mencampur semen-pasir-air & 8 & 7 & 10 \\
Melapisi cetakan dengan oli & 5 & 2 & 4 \\
Pencetakan awal & 7 & 4 & 8 \\
Pemberian rangka & 6 & 2 & 6 \\
Cetak lapisan kedua & 5 & 4 & 5 \\
Cetak lapisan ketiga & 5 & 3 & 4 \\
Melepas cetakan & 7 & 2 & 7 \\
Proses ukir & 6 & 4 & 7 \\
Proses finishing & 8 & 4 & 9 \\
\hline
\end{tabular}

Berdasarkan skor REBA, pengkatagorian dan tindakan perbaikan dapat dilihat pada Tabel 8.

Tabel 8 Pengkategorian Skor REBA

\begin{tabular}{cccc}
\hline $\begin{array}{c}\text { Action } \\
\text { Level }\end{array}$ & $\begin{array}{c}\text { Skor } \\
\text { REBA }\end{array}$ & Level Resiko & Tindakan Perbaikan \\
\hline 0 & 1 & Bisa Diabaikan & Tidak perlu \\
1 & $2-3$ & Rendah & Mungkin perlu \\
2 & $4-7$ & Sedang & Perlu \\
3 & $8-10$ & Tinggi & Perlu segera \\
4 & $11+$ & Sangat Tinggi & Perlu saat ini juga \\
\hline
\end{tabular}

Setelah mengetahui level risiko dari postur kerja proses produksi sanitair maka didapatkan hasil Pengkategorian Skor REBA. Pengkategorian Skor REBA dapat dilihat pada Tabel 9.

Tabel 9 Rekapitulasi Pengkategorian Skor REBA

\begin{tabular}{|c|c|c|c|}
\hline $\begin{array}{c}\text { Skor } \\
\text { REBA }\end{array}$ & $\begin{array}{c}\text { Level } \\
\text { Resiko }\end{array}$ & Tindakan & Postur Kerja \\
\hline $4-7$ & Sedang & Perlu & $\begin{array}{ll}\cdot & \text { Melapisi cetakan dengan oli } \\
\text {. } & \text { Cetak lapisan ketiga } \\
\cdot & \text { Cetak lapisan kedua } \\
\text {. } & \text { Pemberian rangka } \\
\text {. } & \text { Pelepasan cetakan } \\
\text {. } & \text { Proses ukir }\end{array}$ \\
\hline $8-10$ & Tinggi & $\begin{array}{l}\text { Perlu } \\
\text { segera }\end{array}$ & $\begin{array}{ll}\cdot & \text { Pencetakan awal } \\
\cdot & \text { Campur semen-cat bubuk-air } \\
\cdot & \text { Campur semen-pasir-air } \\
. & \text { Proses finishing }\end{array}$ \\
\hline
\end{tabular}


Berdasarkan Tabel 9, terdapat 6 postur kerja dengan level risiko sedang terkena MSDs dan terdapat 4 postur kerja dengan risiko tinggi terkena MSDs. Seluruh postur kerja tenaga kerja di proses produksi sanitair mini di CV. Wijaya Kusuma memerlukan tindakan perbaikan postur kerja.

\subsection{Usulan Perbaikan}

Hasil analisa postur kerja di CV. Wijaya Kusuma, banyak postur kerja dapat menimbulkan risiko cedera musculoskeletal disorders. Hal ini terlihat pada nilai kategori metode REBA. Hasil pengategorian terdapat kategori sedang dan tinggi untuk menurunkan risiko cedera musculoskeletal disorders. Usulan yang dilakukan adalah memperbaiki 2 postur kerja untuk semua proses produksi sanitair di CV. Wijaya Kusuma. Usulan perbaikan berdiri dan usulan perbaikan duduk dapat dilihat Gambar 4 .
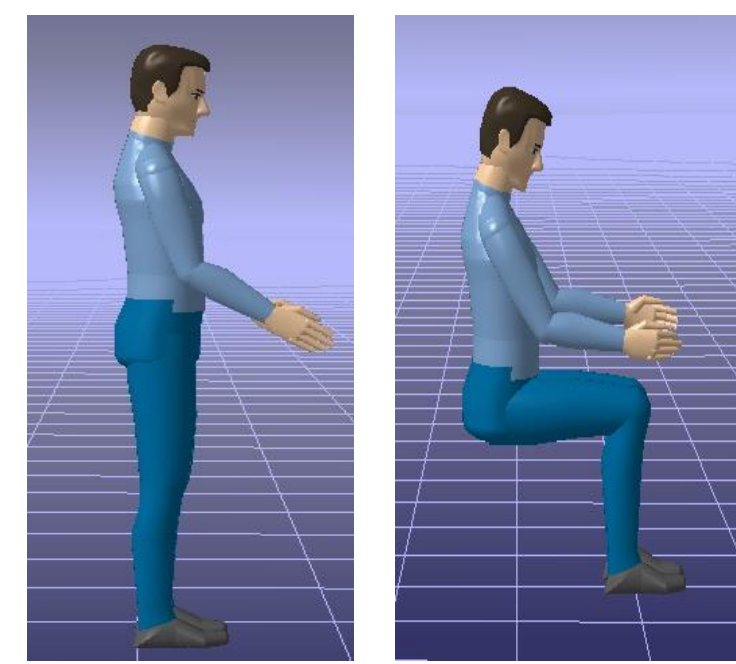

Gambar 4 Usulan perbaikan berdiri dan duduk

Skor REBA dari usulan perbaikan postur kerja dari tenaga kerja CV. Wijaya Kusuma maka didapatkan hasil yang bisa dilihat pada Tabel 10.

Tabel 10 Rekapitulasi Pengkategorian Skor REBA

\begin{tabular}{|c|c|c|c|}
\hline $\begin{array}{c}\text { Skor } \\
\text { REBA }\end{array}$ & Level Resiko & Tindakan & Postur Kerja \\
\hline 1 & $\begin{array}{c}\text { Bisa } \\
\text { Diabaikan }\end{array}$ & Tidak perlu & - Usulan perbaikan, postur kerja berdiri \\
\hline 3 & Rendah & $\begin{array}{l}\text { Mungkin } \\
\text { Perlu }\end{array}$ & Usulan perbaikan, postur kerja duduk \\
\hline
\end{tabular}

Berdasarkan Tabel 10 dapat dilihat terdapat postur kerja berdiri mendapatkan level risiko yang bisa diabaikan dan untuk usulan perbaikan postur kerja duduk mendapatkan level risiko rendah untuk terkena MSDs.

Usulan perbaikan postur kerja berdiri disarankan menggunakan meja agar usulan perbaikan postur kerja dapat dilakukan. Usulan perbaikan, postur kerja berdiri dapat di aplikasikan pada proses pengadukan bahan baku, melapisi cetakan dengan oli, proses pencetakan awal, pemberian rangka, proses pencetakan akhir, dan pelepasan cetakan.

Usulan perbaikan postur kerja duduk, disarankan untuk bekerja di atas meja dan duduk di kursi sandar agar usulan perbaikan postur kerja dapat dilakukan. Usulan 
perbaikan postur kerja duduk dapat di aplikasikan pada proses ukir dan proses finishing.

\section{Simpulan}

Penyebab terjadinya keluhan musculoskeletal disorder pada tenaga kerja produksi CV. Wijaya Kusuma adalah pada postur kerja para tenaga kerja di seluruh proses produksi saat memproduksi sanitair mini yang menunjukkan skor REBA tinggi, terdapat 6 postur kerja dengan level risiko "sedang" terkena MSDs dan terdapat 4 postur kerja dengan risiko "tinggi” terkena MSDs. Solusi berupa perbaikan postur kerja berdiri dan duduk saat memproduksi sanitair mini, dari usulan perbaikan tersebut didapatkan skor REBA dari usulan perbaikan postur kerja berdiri sebesar 1 yang memiliki level risiko bisa diabaikan dan untuk usulan perbaikan postur kerja duduk didapatkan skor REBA sebesar 3 yang memiliki risiko rendah.

\section{Referensi}

[1] E. Nurmianto, Ergonomi konsep dasar dan aplikasinya. Surabaya: PT Guna Widya, 1996.

[2] S. H. Tarwaka and L. Sudiajeng, Ergonomi untuk keselamatan, kesehatan kerja dan produktivitas. Surakarta: UNIBA, 2004.

[3] F. Alexander, "Identifikasi Risiko Ergonomi Pada Stasiun Perakitan Daun Sirip Diffuser Di PT X," J@ Ti Undip: Jurnal Teknik Industri, vol. 3, pp. 108-117, 2008.

[4] S. Higgnet and L. Mcatamney, "Technical Note, Rapid Entire Body Assessment," Applied Ergonomics, vol. 31, pp. 201-205, 2000.

[5] K. H. Kroemer, H. B. Kroemer, and K. E. Kroemer-Elbert, Ergonomics: how to design for ease and efficiency: Pearson College Division, 2001. 